\title{
The intestinal transport of zinc studied using brush-border-membrane vesicles from the piglet
}

\author{
BY PETER BLAKEBOROUGH \\ Department of Food Quality and Human Nutrition, AFRC Institute of Food Research, \\ Reading Laboratory, Shinfield, Reading RG2 $9 A T$ \\ AND DALLYN N. SALTER \\ Department of Pig Nutrition and Production, Animal and Grassland Research Institute, \\ Shinfield, Reading RG29AQ
}

(Received 1 August 1986 - Accepted 11 August 1986)

\begin{abstract}
1. Brush-border-membrane vesicles were prepared from piglet small intestines and the uptake of ${ }^{66} \mathrm{Zn}$ was studied using a rapid filtration assay. The mechanism of ${ }^{85} \mathrm{Zn}$ uptake was complex and two processes were identified.

2. In the first process, ${ }^{65} \mathrm{Zn}$ uptake was rapid, reached equilibrium in 5-15 min and had an optimum pH of 7.5. The uptake was saturable and involved both binding to, and transport across, the membrane. The initial phase of ${ }^{65} \mathrm{Zn}$ uptake ( $1 \mathrm{~min}$ incubation) approached saturation at high levels of substrate ${ }^{65} \mathrm{Zn}$ and a Michaelis-Menten constant $\left(K_{\mathrm{m}}\right)$ of $67.0 \mu \mathrm{M}$ was calculated. Maximum uptake at equilibrium was approximately $100 \mathrm{nmol} / \mathrm{mg}$ protein. Cupric, ferrous and ferric ions had no effect on the uptake, but cadmium ions inhibited it competitively. The results are consistent with a carrier-mediated process, possibly involving a protein receptor in the membrane which is specific for $\mathrm{Zn}$ and elements close to it in the periodic table. Lactoferrin stimulated ${ }^{65} \mathrm{Zn}$ uptake by approximately $20 \%$ when pre-incubated with ${ }^{65} \mathrm{Zn}$ at a concentration of $0.01 \mu \mathrm{g} / \mathrm{ml}$. It had no significant effect on ${ }^{65} \mathrm{Zn}$ uptake at higher concentrations or when pre-incubated with brush-border-membrane vesicles.

3. The second mechanism of ${ }^{65} \mathrm{Zn}$ uptake was linear with respect to time and involved binding to the membrane only. It was inhibited by all divalent and trivalent metal ions tested and is probably a passive binding process.

4. The results are discussed with respect to the use of brush-border-membrane vesicles in examining the role of nutrient interactions and their effect on the biological availability of nutrients.
\end{abstract}

The intestinal absorption of zinc has been studied using a variety of techniques. For in vivo studies workers have used intestinal loops (Davies, 1980), intestinal perfusion (Antonson et al. 1979), radiotracer techniques with intact animals (Becker \& Hoeckstra, 1970) and metabolic balance studies (Weigand \& Kirchgessner, 1976). In addition, in vitro techniques using intestinal segments and strips (Kowarski et al. 1974), everted intestinal sacs (Oberleas et al. 1966), isolated perfused intestines (Smith et al. 1978) and intestinal brush-border-membrane vesicles (Menard \& Cousins, 1983a) have also been used.

Of all these techniques the simplest involves the use of brush-border-membrane vesicles. These are prepared from homogenates of intestinal mucosa by differential centrifugation and form closed, right-side-out vesicles (Kessler et al. 1978) retaining biochemical functions and are ideally suited for transport studies (Murer \& Kinne, 1980; Sachs et al. 1980).

Menard \& Cousins (1983a) have characterized $\mathrm{Zn}$ uptake by rat intestinal brush-border membranes as saturable at low $(200 \mu \mathrm{M})$ and non-saturable at high (1 mM) initial concentrations of $\mathrm{Zn}$. Maximal $\mathrm{Zn}$ uptake was increased when the rats were fed on $\mathrm{Zn}$-deplete as compared with $\mathrm{Zn}$-replete diets. Citrate and picolinate, two potential intestinal $\mathrm{Zn}$ binding ligands, both inhibited $\mathrm{Zn}$ uptake (Menard \& Cousins, 1983b).

In the present study a further characterization of $\mathrm{Zn}$ uptake by brush-border-membrane vesicles was carried out and the effect of other trace metals and the protein lactoferrin on $\mathrm{Zn}$ uptake was ascertained. Vesicles were isolated from piglet intestines. The pig is considered to be a good model for the human in studies of intestinal absorption; the general 
structure, physiology and metabolism of the pig's gastrointestinal tract being similar in many respects to that of the infant and adult human (Clarke \& Hardy, 1971; Dodds, 1982; Fransson et al. 1983).

\section{MATERIALS AND METHODS}

Materials

${ }^{65} \mathrm{ZnCl}_{2}(20 \mu \mathrm{Ci} / \mu \mathrm{mol})$ was obtained from Amersham International plc, Amersham, Bucks. Cellobiose was purchased from Sigma Chemical Co., Poole, Dorset. All other chemicals, including cupric chloride, ferrous chloride, ferric chloride and cadmium chloride were purchased from BDH Chemicals, Poole, Dorset and were of analytical grade where possible. Lactoferrin was purified from human milk as described by Blakeborough et al. (1983).

\section{Preparation of brush-border-membrane vesicles}

Piglets were obtained from the Institute's piggery and given a milk-substitute diet until 14 or $28 \mathrm{~d}$ old (Braude \& Newport, 1973). They were then killed and the whole small intestine was excised and rinsed through with ice-cold saline $(9 \mathrm{~g}$ sodium chloride/l). Intestines were frozen at $-20^{\circ}$ until required.

Brush-border-membrane vesicles were prepared from the frozen intestines as described by Booth \& Kenny (1974). Briefly, the enterocytes were released from connective tissue by vortex mixing and filtration. They were then homogenized in a Waring-type blender and diluted 1:6 with water. Brush-border-membranes were separated from other cell components by the addition of calcium chloride to $10 \mathrm{~mm}$ final concentration (which aggregates all other cell membranes except the brush borders), followed by differential centrifugation. The final membrane pellets were purified ten to twenty-fold over the initial homogenates, as judged by alkaline phosphatase (EC 3.1.3.1) assay (a marker for brush-border membranes) and were judged pure enough for uptake studies to be carried out.

\section{Experimental}

Experiments to study the uptake of ${ }^{65} \mathrm{Zn}$ were done in a final volume of $0.5 \mathrm{ml}$, containing $20 \mathrm{~mm}$-Tris hydrochloride ( $\mathrm{pH} 7-9$ ) or $20 \mathrm{~mm}$-sodium acetate ( $\mathrm{pH} 4-6)$ and $1-100 \mu \mathrm{M}-{ }^{65} \mathrm{Zn}$. Other additions to the incubation medium were as follows. Cellobiose (10,25 and $50 \mathrm{~g} / \mathrm{l})$ was added in experiments investigating the effect of medium osmotic pressure on ${ }^{65} \mathrm{Zn}$ uptake. Other trace metals (cupric, ferrous, ferric and cadmium ions) were added, in concentrations of 20 and $100 \mu \mathrm{M}$ to investigate their possible inhibitory effects on ${ }^{65} \mathrm{Zn}$ uptake. The effect of lactoferrin on ${ }^{65} \mathrm{Zn}$ uptake was studied using two different systems. The protein was pre-incubated either with ${ }^{65} \mathrm{Zn}$ (to $0.01,1$ or $100 \mu \mathrm{g} / \mathrm{ml}$ final concentration) or the brush-border membranes (to $1: 1000,1: 100$ or $1: 10(\mathrm{mg} / \mathrm{mg}$ ) relative to membrane protein concentration) before initiation of the reaction.

Reactions were initiated by the addition of the brush-border membranes ( $50 \mu \mathrm{g}$ protein) to these mixtures, and were conducted for $1-30 \mathrm{~min}$ in a water-bath at $25^{\circ}$. They were

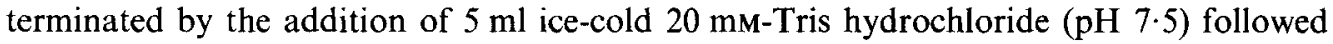
by rapid filtration through a cellulose nitrate membrane of porosity $0.45 \mu \mathrm{m}$ (Whatman Ltd, Maidstone, Kent). This procedure was done on the bench using a water pump. A further $5 \mathrm{ml}$ of ice-cold buffer served to transfer the sample quantitatively onto the filter. Filters were then washed twice with ice-cold buffer, dried in air and transferred to vials. ${ }^{65} \mathrm{Zn}$ was estimated using a $\gamma$-scintillation spectrometer (Intertech CG 4000). 


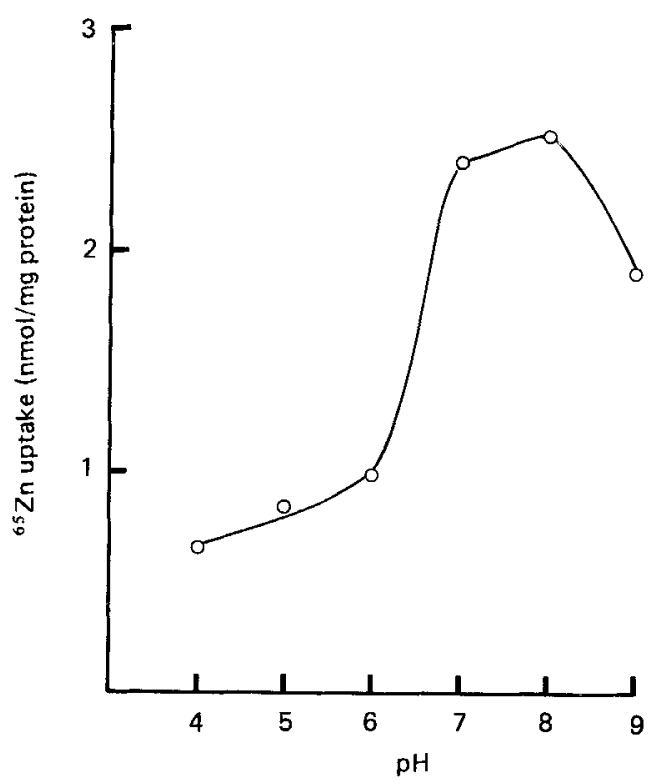

Fig. 1. The effect of $\mathrm{pH}$ on ${ }^{65} \mathrm{Zn}$ uptake. Membranes were incubated with ${ }^{65} \mathrm{Zn}(2 \mu \mathrm{M})$ for $1 \mathrm{~min}$ in buffers of varying pH. Results are the means of three experiments. For details of methods, see p. 46.

\section{Calculation of kinetic constants}

Results for the initial velocity of ${ }^{65} \mathrm{Zn}$ uptake by brush-border membranes (1 min incubation) were calculated as velocity of uptake against substrate concentration. Values of the Michaelis-Menten constant $\left(K_{\mathrm{m}}\right)$ and maximum initial velocity $\left(V_{\max }\right)$ for ${ }^{65} \mathrm{Zn}$ uptake were calculated from these values using the 'direct linear plot' technique (CornishBowden \& Eisenthal, 1974; Eisenthal \& Cornish-Bowden, 1974).

\section{Assays}

Protein was estimated as described by Bensadoun \& Weinstein (1976). Lactoferrin was estimated as described by Blakeborough \& Salter (1986).

\section{RESULTS}

${ }^{65} \mathrm{Zn}$ uptake by brush-border membranes was $\mathrm{pH}$ dependent and optimal at $\mathrm{pH} 7-8$. Uptake was low in the acid region (Fig. 1). A buffer of $20 \mathrm{~mm}$-Tris hydrochloride (pH 7.5) was used for all future experiments.

Uptake of ${ }^{65} \mathrm{Zn}$ was rapid initially and linear with respect to time up to $1-2 \mathrm{~min}$ (Fig. 2). It then decreased until at 15-30 min incubation uptake was again linear with respect to time, but at a much lower rate. The relative proportion of this latter rate to total uptake was small when the initial ${ }^{65} \mathrm{Zn}$ concentration was $10 \mu \mathrm{M}$ and less. However, this proportion increased with increasing ${ }^{65} \mathrm{Zn}$ concentration, yielding up to $50 \%$ of total ${ }^{65} \mathrm{Zn}$ uptake when the initial ${ }^{65} \mathrm{Zn}$ concentration was $50-100 \mu \mathrm{M}$. The plots of uptake against time were similar when the initial ${ }^{65} \mathrm{Zn}$ concentration was 50 or $100 \mu \mathrm{M}$. These results are resolvable into two components of ${ }^{65} \mathrm{Zn}$ uptake: one involving rapid initial uptake which reaches equilibrium in 5-15 min and the other where uptake is linear with respect to time. 


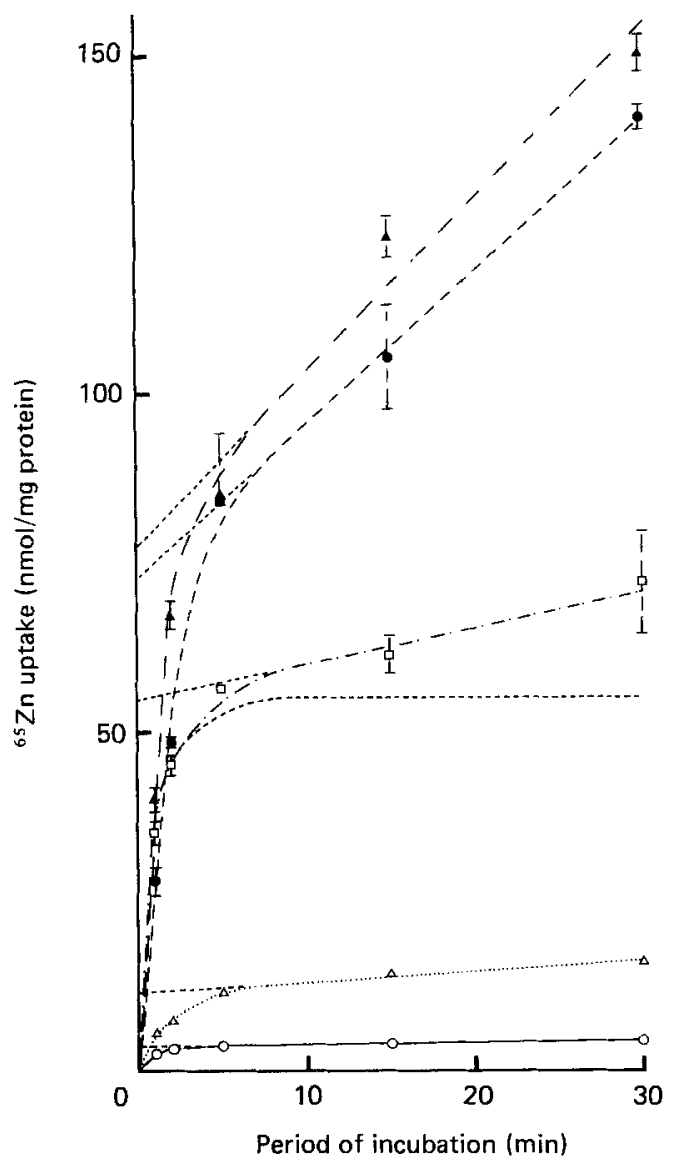

Fig. 2. Uptake of ${ }^{65} \mathrm{Zn}$ with respect to time. Membranes were incubated with ${ }^{65} \mathrm{Zn}(1-100 \mu \mathrm{M})$ for $1-30 \mathrm{~min}$ at $\mathrm{pH} 7 \cdot 5$. Results are the means of three experiments, with their standard errors of the means represented by vertical bars (where no vertical bars are shown the standard errors fall within the symbols representing experimental points). Initial concentrations of ${ }^{65} \mathrm{Zn}$ were as follows: $1 \mu \mathrm{M}(\mathrm{O}-\mathrm{O}), 5 \mu \mathrm{M}(\triangle \ldots \ldots \triangle)$, $10 \mu \mathrm{M}(\square--\square), 50 \mu \mathrm{M}\left(\boldsymbol{O}_{--}\right)$and $100 \mu \mathrm{M}(\mathbf{\Delta}--\mathbf{\Delta}) .(--)$ ), Extrapolation of the slow time-dependent process of ${ }^{65} \mathrm{Zn}$ uptake back to zero and the concomitant construction of the curve for the rapid equilibrium process of ${ }^{65} \mathrm{Zn}$ uptake $\left(10 \mu \mathrm{M}^{63} \mathrm{Zn}\right.$ only).

It was possible to estimate the total contribution from the component which was linear with respect to time by extrapolating the ${ }^{65} \mathrm{Zn}$ uptake from $15-30 \mathrm{~min}$ back to zero (illustrated for example with $10 \mu \mathrm{M}{ }^{65} \mathrm{Zn}$ in Fig. 2). On subtracting this value from the total results, an estimate could be made for the rapid equilibrium component of ${ }^{65} \mathrm{Zn}$ uptake, as follows.

The initial velocity of ${ }^{65} \mathrm{Zn}$ uptake was studied using an incubation period of $1 \mathrm{~min}$. Uptake of ${ }^{85} \mathrm{Zn}$ increased with substrate concentration and saturation was approached at the higher ${ }^{65} \mathrm{Zn}$ concentrations (Fig. $3(a)$ ). These results were calculated to construct a 'direct linear plot', which yielded a calculated $K_{\mathrm{m}}$ for ${ }^{65} \mathrm{Zn}$ uptake of $67 \cdot 0 \mu \mathrm{M}$ with a $V_{\max }$ of $134 \mathrm{nmol}{ }^{65} \mathrm{Zn} / \mathrm{mg}$ protein per min (Fig. $3(b)$ ).

Uptake of ${ }^{65} \mathrm{Zn}$ at equilibrium was calculated as that produced in an incubation of $30 \mathrm{~min}$. A plot of ${ }^{65} \mathrm{Zn}$ taken up against initial ${ }^{65} \mathrm{Zn}$ concentration was sigmoidal in shape. 

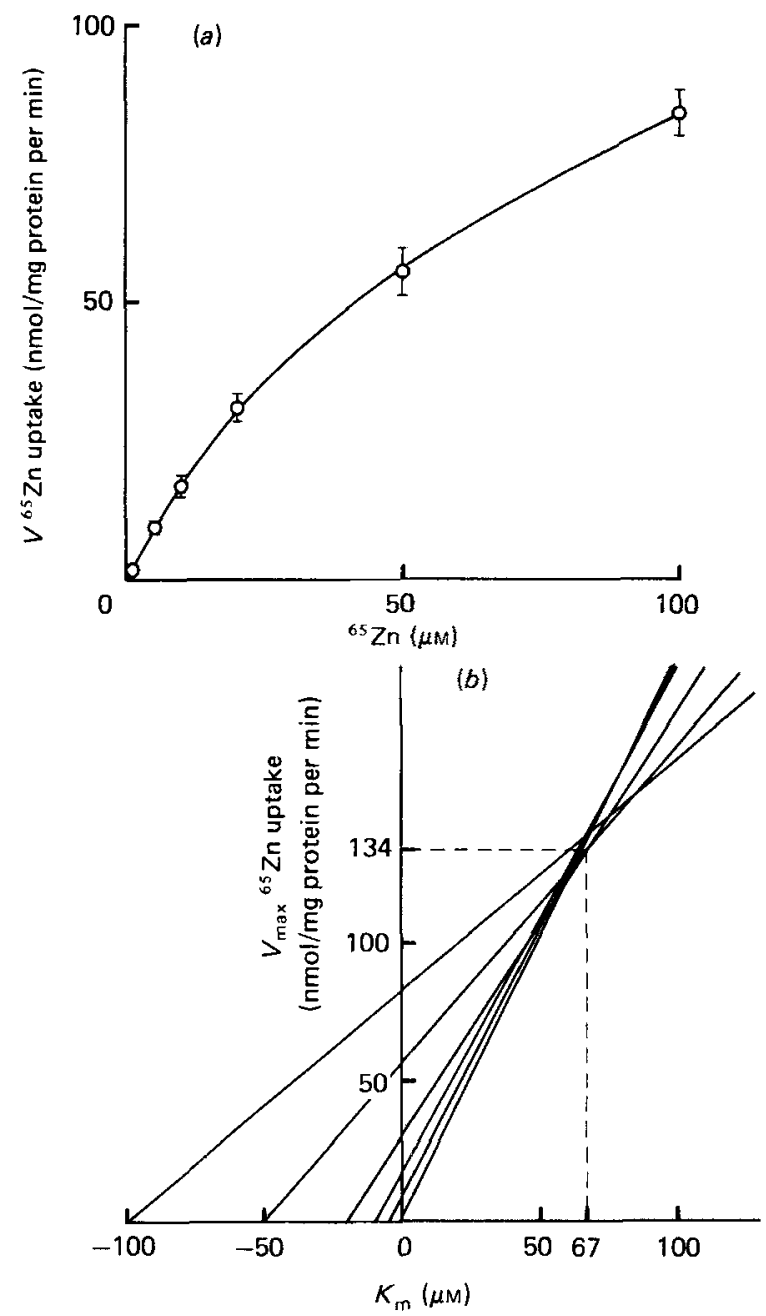

Fig. 3. Initial velocity kinetics of rapid equilibrium ${ }^{65} \mathrm{Zn}$ uptake. Membranes were incubated with ${ }^{65} \mathrm{Zn}$ $(1-100 \mu \mathrm{M})$ for 1 min at $\mathrm{pH} \mathrm{7 \cdot 5.} \mathrm{(a)} \mathrm{Plot} \mathrm{of} \mathrm{velocity} \mathrm{of} \mathrm{uptake}(V)$ against substrate concentration. Results are the means of twenty-seven experiments, with their standard errors of the means represented by vertical bars (where no vertical bars are shown the standard errors fall within the symbols representing experimental points). (b) Results from plot $(a)$ shown as a 'direct linear plot'. $V_{\max }$, initial maximum velocity; $K_{\mathrm{m}}$, Michaelis-Menten constant.

Saturation was approached at the higher ${ }^{65} \mathrm{Zn}$ concentrations where approximately $100 \mathrm{nmol}{ }^{65} \mathrm{Zn} / \mathrm{mg}$ membrane protein were taken up (Fig. 4).

Cellobiose was added to the incubation medium to increase the osmotic pressure by graded amounts. When the initial concentration of ${ }^{65} \mathrm{Zn}$ was $5 \mu \mathrm{M}$, an osmotically sensitive uptake of ${ }^{65} \mathrm{Zn}$ was observed, with decreasing uptake at increasing osmotic pressure (Fig. 5). The plot of ${ }^{65} \mathrm{Zn}$ uptake against the reciprocal of osmotic pressure was linear, and after extrapolation back to infinite osmotic pressure showed net uptake of ${ }^{65} \mathrm{Zn}$ at this point. When the initial ${ }^{65} \mathrm{Zn}$ concentration was $100 \mu \mathrm{M},{ }^{65} \mathrm{Zn}$ uptake was not osmotically sensitive, being relatively constant at all osmotic pressures used.

The effect of other trace metals on ${ }^{65} \mathrm{Zn}$ uptake was investigated using an incubation time 

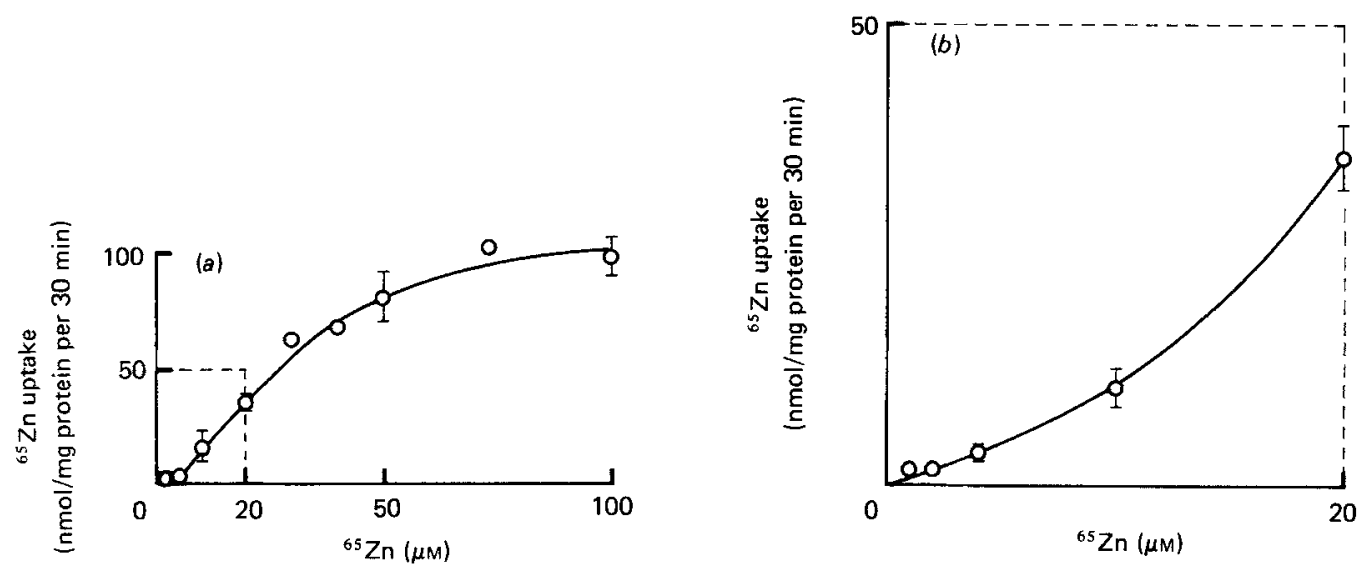

Fig. $4(a)$. Rapid equilibrium uptake of ${ }^{65} \mathrm{Zn}$ at equilibrium. Membranes were incubated with ${ }^{65} \mathrm{Zn}$ $(1-100 \mu \mathrm{M})$ for 15 and $30 \mathrm{~min}$ at $\mathrm{pH} 7 \cdot 5$. The rapid equilibrium component of ${ }^{65} \mathrm{Zn}$ uptake was calculated as (uptake at $30 \mathrm{~min})-(2 \times$ (uptake at $30 \mathrm{~min}$-uptake at $15 \mathrm{~min}))$. Results are the means of nine experiments, with their standard errors of the means represented by vertical bars, except for 30,40 and $75 \mu \mathrm{M}^{-65} \mathrm{Zn}$ (means of three experiments); for 1,2 and $5 \mu \mathrm{M}^{-65} \mathrm{Zn}$ standard errors fall within the symbols representing experimental points. (b) Magnification of the region of uptake from 1 to $20 \mu \mathrm{M}^{-65} \mathrm{Zn}$.

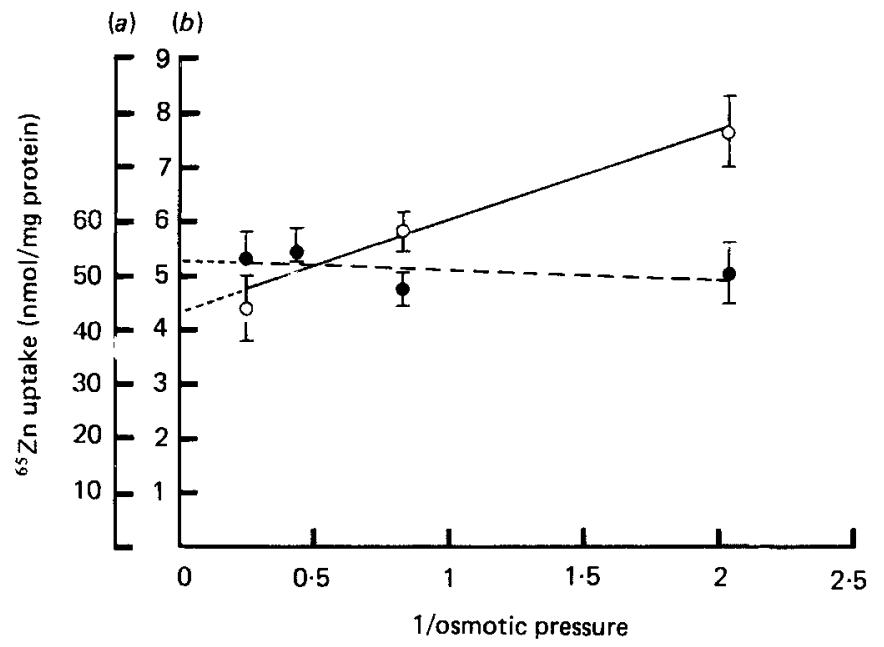

Fig. 5. The effect of increasing the osmotic pressure on ${ }^{65} \mathrm{Zn}$ uptake. Membranes were incubated with (a) $100 \mu \mathrm{M}^{-65} \mathrm{Zn}\left(\mathrm{O}^{--} \mathrm{O}\right)$ or $\left(\right.$ b) $5 \mu \mathrm{M}^{-6} \mathrm{Zn}(\mathrm{O}-\mathrm{O})$ for $1 \mathrm{~min}$ at $\mathrm{pH} 7 \cdot 5$, in the presence of $0,10,25$ and $50 \mathrm{~g}$ cellobiose/l. Results are the means of six experiments, with their standard errors of the means represented by vertical bars.

of $1 \mathrm{~min}$. Results were calculated with no subtraction of the linear component with respect to time. $\mathrm{Cu}^{2+}, \mathrm{Fe}^{2+}$ and $\mathrm{Fe}^{3+}$ had very similar effects on ${ }^{65} \mathrm{Zn}$ uptake (Fig. $6(a, b, c)$ ). No significant effect was observed on ${ }^{65} \mathrm{Zn}$ uptake when the initial ${ }^{65} \mathrm{Zn}$ concentration was low (10 $\mu \mathrm{M}$ and less). However, at higher initial ${ }^{65} \mathrm{Zn}$ concentrations the trace metals caused inhibition of ${ }^{65} \mathrm{Zn}$ uptake, especially in the region $50-100 \mu \mathrm{M}{ }^{65} \mathrm{Zn}$. Analysis by the 'direct linear plot' technique indicated that values for $K_{\mathrm{m}}$ and $V_{\max }$ were reduced by these trace metals (Table 1).

When $\mathrm{Cd}^{2+}$ was used as the competing metal, significant inhibition of ${ }^{65} \mathrm{Zn}$ uptake was 

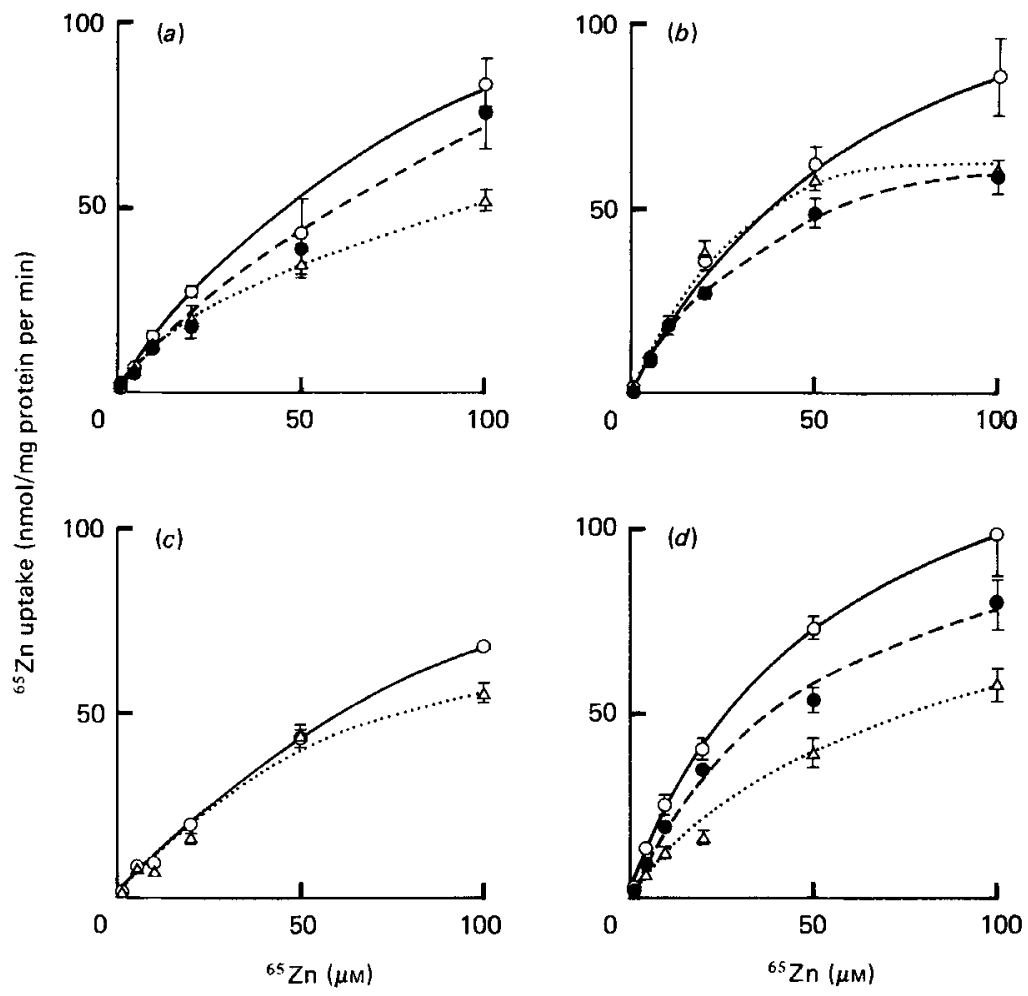

Fig. 6. Effect of trace metals on ${ }^{65} \mathrm{Zn}$ uptake. Membranes were incubated with ${ }^{65} \mathrm{Zn}(1-100 \mu \mathrm{M})$, together with $0(\mathrm{O}-\mathrm{O}), 20(\mathrm{O}-\mathrm{)})$ or $100 \mu \mathrm{M}(\triangle \ldots . . \triangle)$ competing trace metal $((a)$ cupric ion, $(b)$ ferrous ion, (c) ferric ion, (d) cadmium) for $1 \mathrm{~min}$ at $\mathrm{pH} 7 \cdot 5$. Results are the means of three experiments, with their standard errors of the means represented by vertical bars (where no bars are shown the standard errors fall within the symbols representing experimental points).

Table 1. A comparison of kinetic constants calculated for ${ }^{65} \mathrm{Zn}$ uptake by brush-bordermembrane vesicles in the presence of competing metal ions (cupric, ferrous, ferric and cadmium)

(Constants were calculated from results in Fig. 6 using the direct linear plot technique)

\begin{tabular}{|c|c|c|c|}
\hline $\begin{array}{c}\text { Competing } \\
\text { metal }\end{array}$ & $\begin{array}{c}\text { Competing metal } \\
\text { concentration } \\
(\mu \mathrm{M})\end{array}$ & $\begin{array}{l}{ }^{65} \mathrm{Zn} \text { uptake } V_{\max } \\
\text { (nmol/min per mg } \\
\text { membrane protein) }\end{array}$ & $\begin{array}{c}K_{\mathrm{m}} \\
(\mu \mathrm{M})\end{array}$ \\
\hline \multirow[t]{3}{*}{$\mathrm{Cu}^{2+}$} & 0 & $135 \cdot 0$ & $84 \cdot 5$ \\
\hline & 20 & 79.5 & 52.5 \\
\hline & 100 & $77 \cdot 7$ & $61 \cdot 0$ \\
\hline \multirow{3}{*}{$\mathrm{Fe}^{2+}$} & 0 & $148 \cdot 0$ & $74 \cdot 0$ \\
\hline & 20 & $84 \cdot 0$ & $43 \cdot 0$ \\
\hline & 100 & 83.0 & 37.5 \\
\hline \multirow[t]{2}{*}{$\mathrm{Fe}^{3+}$} & 0 & 82.0 & 42.5 \\
\hline & 100 & $41 \cdot 0$ & $30 \cdot 0$ \\
\hline \multirow[t]{3}{*}{$\mathrm{Cd}^{2+}$} & 0 & 143.0 & 43.5 \\
\hline & 20 & 128.5 & $59 \cdot 5$ \\
\hline & 100 & 108.0 & 87.0 \\
\hline
\end{tabular}

$V_{\text {max }}$, maximum initial velocity; $K_{\mathrm{m}}$, Michealis-Menten constant. 
Table 2. The effect of lactoferrin on ${ }^{65} \mathrm{Zn}$ uptake by brush-border-membrane vesicles (Membranes were incubated with ${ }^{65} \mathrm{Zn}(5 \mu \mathrm{M})$ for $1 \mathrm{~min}$ at $25^{\circ}$. Lactoferrin was pre-incubated with $(a)$ the ${ }^{65} \mathrm{Zn}$ solutions for $30 \mathrm{~min}$ at $0^{\circ}$ before the addition of brush-border membranes to initiate the reaction, or $(b)$ the brush-border membranes for $30 \mathrm{~min}$ at $0^{\circ}$ before the initiation of the reaction. Results are the means with their standard errors of three determinations)

\begin{tabular}{|c|c|c|}
\hline & \multicolumn{2}{|c|}{$\begin{array}{c}{ }^{65} \mathrm{Zn} \text { uptake } \\
\text { (nmol/mg protein } \\
\text { per min) }\end{array}$} \\
\hline & Mean & SE \\
\hline \multicolumn{3}{|c|}{ (a) Lactoferrin pre-incubated with ${ }^{65} \mathrm{Zn}(\mu \mathrm{g} / \mathrm{ml})$} \\
\hline 0 & $3 \cdot 32$ & $0 \cdot 06$ \\
\hline 0.01 & $4 \cdot 02 *$ & $0 \cdot 1$ \\
\hline $1 \cdot 0$ & $3 \cdot 97 \mathrm{NS}$ & 0.67 \\
\hline $100 \cdot 0$ & $1 \cdot 76 \mathrm{NS}$ & $0 \cdot 4$ \\
\hline \multicolumn{3}{|c|}{$\begin{array}{l}\text { (b) Lactoferrin pre-incubated with brush-border } \\
\text { membranes ( } \mathrm{mg} / \mathrm{mg} \text { protein) }\end{array}$} \\
\hline 0 & $5 \cdot 0$ & $0 \cdot 1$ \\
\hline $1 / 1000$ & $4 \cdot 73 \mathrm{NS}$ & $0 \cdot 18$ \\
\hline $1 / 100$ & $4 \cdot 43 \mathrm{NS}$ & $0 \cdot 14$ \\
\hline $1 / 10$ & $5 \cdot 28 \mathrm{NS}$ & $0 \cdot 4$ \\
\hline
\end{tabular}

NS, not significant.

$* P<0.05$.

observed at all initial ${ }^{65} \mathrm{Zn}$ concentrations from 1 to $100 \mu \mathrm{M}$ (Fig. $6(d)$ ). The results were used to construct a 'direct linear plot' to calculate values for $K_{\mathrm{m}}$ and $V_{\max }$ (Table 1). The addition of $\mathrm{Cd}^{2+}$ caused the $K_{\mathrm{m}}$ to increase significantly whilst the $V_{\max }$ decreased, though to a smaller extent.

Lactoferrin had no significant effect on ${ }^{65} \mathrm{Zn}$ uptake when it was pre-incubated with brush-border-membrane vesicles (Table 2). However, when incubated with ${ }^{65} \mathrm{Zn}$ at $0.01 \mu \mathrm{g} / \mathrm{ml}$ there was a significant stimulation of ${ }^{65} \mathrm{Zn}$ uptake of approximately $20 \%$. Increasing the lactoferrin concentration abolished this effect and at $100 \mu \mathrm{g}$ lactoferrin $/ \mathrm{ml}$ there was an apparent inhibition of ${ }^{65} \mathrm{Zn}$ uptake which did not, however, approach significance.

\section{DISCUSSION}

Results show that brush-border-membrane vesicles were able to take up ${ }^{65} \mathrm{Zn}$ by at least two separate mechanisms. Plots of ${ }^{65} \mathrm{Zn}$ uptake against time were resolvable into a component which was initially linear and rapid but reached equilibrium within 5-15 min, and a component which was linear with respect to time. The rapid equilibrium process dominated when the initial ${ }^{65} \mathrm{Zn}$ concentration was low $(\leqslant 10 \mu \mathrm{M})$. However, the slow time-dependent process increased with the initial concentration of ${ }^{65} \mathrm{Zn}$ and at $100 \mu \mathrm{M}{ }^{65} \mathrm{Zn}$ it accounted for approximately $50 \%$ of the ${ }^{65} \mathrm{Zn}$ uptake.

Uptake of ${ }^{65} \mathrm{Zn}$ by the rapid equilibrium mechanism was $\mathrm{pH}$ dependent, with a pronounced optimum, and was clearly shown to be saturable by both initial velocity and equilibrium uptake studies. These results are consistent with a mechanism whereby $\mathrm{Zn}$ associates with a saturable carrier in the brush-border membrane, usually assumed to be a protein (Lever, 1980). The $K_{\mathrm{m}}$ for the rapid equilibrium mechanism of ${ }^{65} \mathrm{Zn}$ uptake $(67.0 \mu \mathrm{M})$ was approximately sixfold lower than that observed by Menard \& Cousins 
(1983a) (380-440 $\mu \mathrm{M})$. This may represent species differences between the pig and rat. However, the lowest initial concentration of ${ }^{65} \mathrm{Zn}(200 \mu \mathrm{M})$ used by Menard \& Cousins (1983a) was greater than the highest $(100 \mu \mathrm{M})$ used in the present experiments and the differences in observed $K_{\mathrm{m}}$ may be indicative of different $\mathrm{Zn}$ uptake mechanisms. $\mathrm{Zn}$ is present in human milk at a concentration of approximately $20 \mu \mathrm{M}$, whereas in cow's milk the concentration is up to threefold higher (George \& Lebenthal, 1981). The ${ }^{65} \mathrm{Zn}$ concentrations used in the present study were thus similar to in vivo lumen concentrations of $\mathrm{Zn}$ in the human infant. The sigmoidal-shaped curve observed for the uptake of ${ }^{65} \mathrm{Zn}$ at equilibrium does not necessarily mean a complex mechanism is operating as such observations are often made for simple membrane-substrate interactions (Vincent \& Thellier, 1983).

Uptake of ${ }^{65} \mathrm{Zn}$ at an initial concentration of $5 \mu \mathrm{M}^{-65} \mathrm{Zn}$ contained both osmotically sensitive and insensitive components. Osmotically sensitive uptake is usually interpreted in terms of transport across the membrane, whereas osmotically insenstive uptake is considered to be a binding phenomenon (Hopfer et al. 1973). The rapid equilibrium mechanism of ${ }^{65} \mathrm{Zn}$ uptake therefore involves transport across the brush-border membrane and can be considered as part of the absorptive process. The time-dependent mechanism of ${ }^{65} \mathrm{Zn}$ uptake was observed most clearly when the initial concentration of ${ }^{65} \mathrm{Zn}$ was $\geqslant 50 \mu \mathrm{M}$. The uptake was osmotically insensitive when the initial concentration of ${ }^{65} \mathrm{Zn}$ was $100 \mu \mathrm{M}$, indicating that a binding process only was taking place. Brush-border-membrane vesicles can therefore be used to characterize ${ }^{65} \mathrm{Zn}$ uptake and rate-constants for the uptake can easily be derived It was also possible to investigate the effect of other nutrients on ${ }^{65} \mathrm{Zn}$ uptake. Of other trace metals tested, only $\mathrm{Cd}^{2+}$ inhibited ${ }^{65} \mathrm{Zn}$ uptake when the initial concentration of ${ }^{65} \mathrm{Zn}$ was less than $10 \mu \mathrm{M}$. $\mathrm{Cd}^{2+}$ acted significantly to increase $K_{\mathrm{m}}$ for ${ }^{65} \mathrm{Zn}$ uptake, whilst $V_{\max }$ was slightly decreased. The inhibition was therefore largely competitive, with possibly some contribution from a non-competitive mechanism (Eisenthal \& CornishBowden, 1974). These results suggest that the membrane carrier involved in the rapid equilibrium mechanism of ${ }^{65} \mathrm{Zn}$ uptake is relatively specific to $\mathrm{Zn}$ and elements close to it in the periodic table. $\mathrm{Cu}^{2+}, \mathrm{Fe}^{2+}$ and $\mathrm{Fe}^{3+}$ inhibited ${ }^{65} \mathrm{Zn}$ uptake when the initial ${ }^{65} \mathrm{Zn}$ concentration was $\geqslant 50 \mu \mathrm{M}$. Both $K_{\mathrm{m}}$ and $V_{\max }$ were reduced by these metal ions and the inhibition seemed to be uncompetitive in nature (Eisenthal \& Cornish-Bowden, 1974). The time-dependent uptake of ${ }^{65} \mathrm{Zn}$ appears to be a binding process shared with other divalent and trivalent metal ions. It probably involves passive binding to anionic sites on the brush-border membrane, e.g. phospholipids and sugar residues of glycoproteins, and is not a direct mechanism of absorption.

Lactoferrin is known to bind to the mucosal surface of the intestine (Masson et al. 1969) and to $\mathrm{Zn}$ (Blakeborough \& Salter, 1986). When pre-incubated with brush-bordermembrane vesicles, the protein had no effect on ${ }^{65} \mathrm{Zn}$ uptake by the rapid equilibrium mechanism. However, when pre-incubated with ${ }^{65} \mathrm{Zn}$, lactoferrin stimulated ${ }^{65} \mathrm{Zn}$ uptake when its concentration was low $(0.01 \mu \mathrm{g} / \mathrm{ml})$ and possibly inhibited ${ }^{65} \mathrm{Zn}$ uptake when its concentration was high $(100 \mu \mathrm{g} / \mathrm{ml})$. This phenomenon may have relevance to $\mathrm{Zn}$ absorption by the human infant. The major Zn-binding components of cow's and human milks are proteins, respectively casein and lactoferrin (Blakeborough et al. 1983). We have shown that casein was poorly digested by the piglet gastrointestinal tract and formed curds which trapped $\mathrm{Zn}$ in a solid form throughout the small intestine. In contrast human milk was digested so that almost all the $\mathrm{Zn}$ was in a soluble form in the piglet small intestine, although still largely bound to proteins, including lactoferrin (Blakeborough et al. 1986).

The results reported here would support the suggestion that lactoferrin can act to donate $\mathrm{Zn}$ to its absorption sites on the small intestinal mucosa. It would be interesting to discover the optimum levels of intestinal lactoferrin which stimulate or inhibit $\mathrm{Zn}$ absorption, and 
correlate these to lactoferrin levels in the small intestine of piglets given various infant feeds.

Both the present paper and that of Menard \& Cousins ( $1983 b$ ) show that the effect of other nutrients on intestinal $\mathrm{Zn}$ transport can be studied using brush-border-membrane vesicles. The great advantage of this procedure over in vivo techniques is that the effect of specific nutrients can be studied in isolation, without having to take into account other dietary factors. For example, no consistent pattern of results has emerged on the effect of citrate and picolinate on $\mathrm{Zn}$ absorption from in vivo experiments (Giroux \& Prakash, 1977; Evans \& Johnson, 1980; Flagstad, 1981; Hurley et al. 1982), whereas with brush-border-membrane vesicles both nutrients clearly inhibit $\mathrm{Zn}$ transport (Menard \& Cousins 1983b).

It is true that the simple buffer systems used in experiments with brush-border-membrane vesicles will not be the same as conditions in vivo in the intestinal lumen. Conditions were such that ${ }^{65} \mathrm{Zn}$ uptake was at a maximum. It would be interesting in future experiments to use more complex foodstuffs extrinsically labelled with ${ }^{65} \mathrm{Zn}$ (Sandström et al. 1983a,b) which could be enzymically modified to mimic digestive processes (Wien \& Schwartz, 1985) in studies of ${ }^{65} \mathrm{Zn}$ uptake by brush-border membranes. Initially the $\mathrm{Zn}$-binding protein complexes of human and cow's milks would be tested to observe their effects on ${ }^{65} \mathrm{Zn}$ uptake.

In conclusion, brush-border-membrane vesicles provide a simple, versatile system to study the factors affecting $\mathrm{Zn}$ uptake by the intestine. They provide a model system to study many different compounds, drugs and poisons as well as nutrients, for nutritionists interested in the molecular events involved in intestinal absorption.

The authors thank Ms Sheila G. Neville for assistance with the research, and Dr Michael $J$. Newport for the provision of the piglets.

\section{REFEREN CES}

Antonson, D. L., Barak, A. J. \& Vanderhoof, J. A. (1979). Journal of Nutrition 109, 142-147.

Becker, W. M. \& Hoeckstra, W. G. (1970). In Intestinal Absorption of Metal Ions, Trace Elements and Radionuclides, pp. 229-256 [S. C. Skoryna and D. Waldron-Edwards, editors]. New York: Pergamon Press.

Bensadoun, A. \& Weinstein, D. (1976). Analytical Biochemistry 70, 241-250.

Blakeborough, P., Gurr, M. I. \& Salter, D. N. (1986). British Journal of Nutrition 55, $209-217$.

Blakeborough, P. \& Salter, D. N. (1986). In Trace Elements in Man and Animals, TEMA 5, pp. 420-423

[C. F. Mills, I. Bremner and J. K. Chesters, editors]. Slough: Commonwealth Agricultural Bureaux.

Blakeborough, P., Salter, D. N. \& Gurr, M. I. (1983). Biochemical Journal 209, 505-512.

Booth, A. G. \& Kenny, A. J. (1974). Biochemical Journal 142, 575-581.

Braude, R. \& Newport, M. J. (1973). British Journal of Nutrition 29, 447-455.

Clarke, R. M. \& Hardy, R. N. (1971). Journal of Anatomy 108, 63-77.

Cornish-Bowden, A. \& Eisenthal, R. (1974). Biochemical Journal 139, 721-730.

Davies, N. T. (1980). British Journal of Nutrition 43, 189-203.

Dodds, W. J. (1982). Federation Proceedings 41, 247-256.

Eisenthal, R. \& Cornish-Bowden, A. (1974). Biochemical Journal 139, 715-720.

Evans, G. W. \& Johnson, E. C. (1980). Journal of Nutrition 110, 1076-1080.

Flagstad, T. (1981). Journal of Nutrition 111, 1996-1999.

Fransson, G.-B., Thorén-Tolling, K., Jones, B., Hambraeus, L. \& Lönnerdal, B. (1983). Nutrition Research 3, 373-384.

George, D. E. \& Lebenthal, E. (1981). In Textbook of Gastroenterology and Nutrition in Infancy, pp. 295-320

[E. Lebenthal, editor]. New York: Raven Press.

Giroux, E. \& Prakash, N. J. (1977). Journal of Pharmaceutical Science 66, 391-392.

Hopfer, U., Nelson, K., Perrotto, J. \& Isselbacher, K. I. (1973). Journal of Biological Chemistry 248, $25-32$.

Hurley, L. S., Keen, C. L., Young, H. M. \& Lönnerdal, B. (1982). Federation Proceedings 41, 2982.

Kessler, M., Acuto, O., Storelli, C., Murer, H., Müller, M. \& Semenza, G. (1978). Biochimica et Biophysica Acta 506, 136-154.

Kowarski, S., Blair-Stanek, C. S. \& Schachter, D. (1974). American Journal of Physiology 226, $401-407$.

Lever, J. E. (1980). CRC Critical Reviews of Biochemistry 7, 187-246.

Masson, P. L., Heremans, J. F., Schonne, E. \& Crabbe, P. A. (1969). Protides of the Biological Fluids 16, $633-638$.

Menard, M. P. \& Cousins, R. J. (1983a). Journal of Nutrition 113, 1434-1442.

Menard, M. P. \& Cousins, R. J. (1983b). Journal of Nutrition 113, 1653-1656. 
Murer, H. \& Kinne, R. (1980). Journal of Membrane Biology 55, 81-95.

Oberleas, D., Muhrer, M. E. \& O'Dell, B. L. (1966). Journal of Nutrition 90, 56-62.

Sachs, G., Jackson, R. J. \& Rabon, E. C. (1980). American Journal of Physiology 238, G151-G164.

Sandström, B., Cederblad, A. \& Lönnerdal, B. (1983a). American Journal of Diseases of Children 137, 726-729.

Sandström, B., Keen, C. L. \& Lönnerdal, B. (1983 b). American Journal of Clinical Nutrition 38, 420-428.

Smith, K. T., Cousins, R. J., Silbon, B. L. \& Failla, M. L. (1978). Journal of Nutrition 108, 1849-1857.

Vincent, J. C. \& Thellier, M. (1983). Biophysical Journal 41, 23-28.

Weigand, E. \& Kirchgessner, M. (1976). Nutrition and Metabolism 20, 307-313.

Wien, E. M. \& Schwartz, R. (1985). In Nutritional Bioavailability of Calcium, ACS Symposium Series no. 275, pp. 1-16 [C. Kies, editor]. Washington DC: American Chemical Society. 